
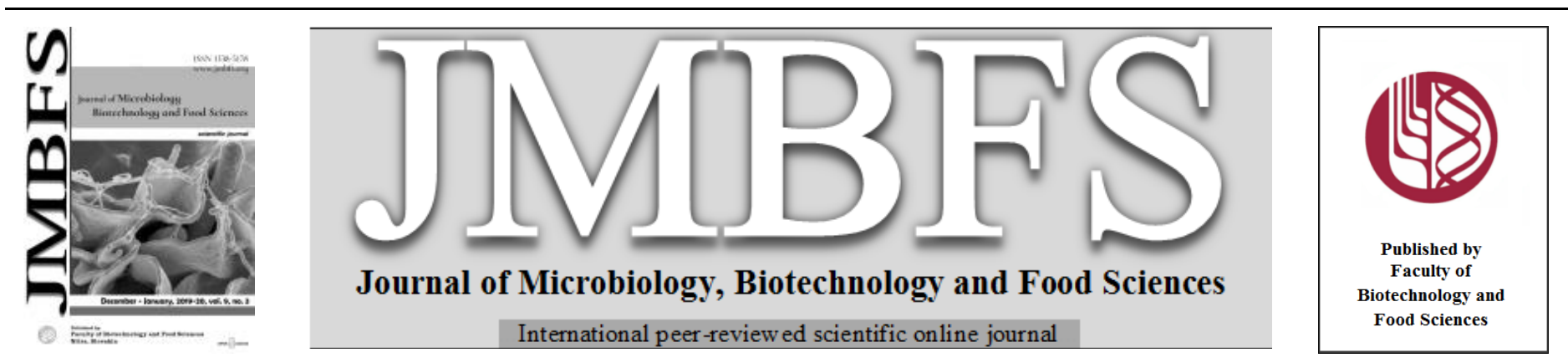

\title{
COMPARATIVE STUDY OF ARTEMISIA HERBA ALBA ASSO AND CITRUS AURANTIUM ESSENTIAL OILS
}

\author{
Asma Boukhennoufa ${ }^{* 1}$, Aicha Tir Touil Meddah ${ }^{1}$, Boumediene Meddah ${ }^{1}$, José Antonio Gabaldón ${ }^{2}$ and Pascal Sonnet $^{3}$ \\ Address(es): PhD Student. Asma Boukhennoufa, \\ ${ }^{1}$ Laboratory of Bioconversion, Microbiology Engineering and Health Safety, Faculty SNV, University of Mascara, Algeria. \\ ${ }^{2}$ Department of Food Technology and Nutrition, San Anthony Catholic University of Murcia, Avenida de los Jerónimos s/n, 30107 Murcia, Guadalupe, Spain. \\ ${ }^{3}$ Laboratory of Glucides-Team Thera- FRE-CNRS 3517, Faculty of Pharmacy, University of Picardie, Amiens, France.
}

*Corresponding author: asma.boukhennoufa@univ-mascara.dz

doi: 10.15414/jmbfs.2019/20.9.3.622-627

\section{ARTICLE INFO}

Received 26. 12. 2018

Revised 4. 8. 2019

Accepted 26. 8. 2019

Published 1. 12. 2019

\section{Regular article}

OPEN ACCESS

\begin{abstract}
Artemisia herba alba asso, peel and leaves of Citrus aurantium grown in the western Algerian city (Mascara) were subjected to hydrodistillation by Clevenger dispositive. The essential oils obtained were analyzed by gas chromatography coupled to mass spectrometry and used for the study of the antifungal activity against five clinical strains of Candida albicans. The results of chemical analysis revealed 40 constituents in Artemisia essential oil, where the major components were camphor (34.89\%) and chrysantenone $(19.60 \%)$. While, the main component of peel and leaves of Citrus essential oils was the lineal $(42.33 \%, 60.62 \%)$ respectively. The lowest minimum inhibitory concentration value was found in the case of Artemisia essential oil $(1.95 \mu 1 / \mathrm{ml})$ against the (S3) Candida albicans strain. The experimental results confirmed that these extracts are marked by significant anti-fungal activity, which can be used as alternative drugs against candidiasis.
\end{abstract}

Keywords: GC/MS, Artemisia herba alba, Citrus aurantium, Candida albicans, Antifungal activity

\section{INTRODUCTION}

Plants have been a major source of therapeutic agents since ancient time, these resources and their derivatives are thus looked also as an important commodity item of international trade and commerce (Kurian and Sankar, 2007). The Artemisia is one of the largest genera of the family of Asteraceae, bushy subshrub widespread in the highlands, and the steppe zones . It is characteristic of the deserts of the Middle East and the North Africa. This plant forms clumps of $(0.3$ to $0.8 \mathrm{~m})$ from above, dry and whitish appearance. The plant is widely used in traditional medicine in Algeria, to treat gastric and hepatic disorders (Kaddem, 1993). In addition, it was used for their anti-diabetic, leishmanicidal, antibacterial, and antifungal properties (Haouari and Ferchichi, 2009). Various secondary metabolites have been isolated from A. herba-alba, perhaps the most important being the sesquiterpene lactones (Mohamed et al., 2010). Indeed, $A$ herba-alba showed a strong antioxidant activity and very high phenolic content compared to the common nutritional plants (Djeridane et al., 2006). While the second species was Citrus aurantium (bitter orange) belongs to the family of Rutaceae. It is a dark green tree with fragrant white flowers and orange fruit. It is not edible because it tastes bitter (10 m high) (Anonyme, 2001). It is native of tropical, subtropical regions of India, South, northern Australia and New Caledonia. The high rate of acids helps digestion and relieves flatulence. The fruit juice of this plant helps the body to eliminate waste and with its high content of vitamin C, stimulates the immune system defenses (Anonyme, 2001). Citrus peel essential oils are reported to be one of the rich sources of bioactive compounds namely coumarins, flavonoids, carotenes, terpenes and linalool etc. (Mondello et al., 2005). Moreover, essential oils of bitter orange are used for the defense of plants against herbivores, insects and microorganisms (Ainane et al., 2018). Beside, Citrus aurantium essential oils possess antioxidant, antibacterial and fungicidal activities (Zarrad $\boldsymbol{e t}$ al., 2015). The purpose of this study was to investigate the chemical composition of three essential oils by the gas chromatography coupled to mass spectrometry (GC/MS) and to improve their antifungal activities by disc diffusion method on Muller-Hinton agar.

\section{MATERIAL AND METHODS}

\section{Chemicals}

Sodium chloride, cyclohexane, anhydrous sodium sulfate, helium gas, knowing that, the purity of all these chemicals was checked before application.

\section{Plant material}

The vegetal material were Artemisia herba alba asso (aerial part) and Citrus aurantium (peel and leaves). These plants were collected in March 2015 from the west of Algeria. Then, they were identified by several botanists of the department of biology in the faculty of SNV of the University of Mascara. And, they were stored as voucher specimens in the herbarium of the institute under the following codes: Artemisia herba alba asso (AS00006) and Citrus aurantium (RU 00002).

\section{Extraction of essential oils}

The extraction of the essential oil was carried out by the hydrodistillation process. $100 \mathrm{~g}$ of the fresh plant were introduced into a flask filled with one liter of distilled water, the whole was brought to the boil for 3 hours. A quantity of 0.5 $\mathrm{g}$ of sodium chloride $(\mathrm{NaCl})$ was added to the distillate. Then, the mixture was placed in a separating funnel and three successive washes of cyclohexane were achieved. The essential oils obtained were concentrated with rotary evaporator and were dried with anhydrous sodium sulfate. Then, it was stored at $4^{\circ} \mathrm{C}$ until analysis. The yield extraction essential oil was expressed as the weight of essential oil volume obtained on the fresh aerial part weight used (w/w) However, the physicochemical properties of the essential oils are determined according to the AFNOR standards: the relative density at $20{ }^{\circ} \mathrm{C}(\mathrm{T} 75-111)$, the refractive index (T 75-112), and the acid index (T 75-103).

\section{Gas chromatography/mass spectrometry analysis}

GC analysis was carried out using a Gas Chromatograph coupled to a Mass Spectrometer (GC-MS) type Shimadzu QP2010 in the laboratory associate to the department of Food Technology and Nutrition, Catholic University San Antonio of Murcia (Spain). The capillary column used was a DB-5 ms $(25 \mathrm{~m} \times 0.25 \mathrm{~mm} \times$ $0.25 \mu \mathrm{m})$. The injections were made in splitless with $1 \mu \mathrm{L}$ of essential oil diluted to $10 \%$ in cyclohexane. Chromatogram acquisition was in SCAN mode Moreover, Helium was used as the carrier gas at a flow rate of $0.5 \mathrm{~mL}$.min-1. Ion source and interface temperatures were fixed at $250^{\circ} \mathrm{C}$ and $280^{\circ} \mathrm{C}$ respectively. The time of the solvent delay was $4 \mathrm{~min}$. The detector was programmed at 250 ${ }^{\circ} \mathrm{C}$. The mass spectra were recorded over a range of $35-400 \mathrm{~m} / \mathrm{z}$ at $0.3 \mathrm{~s} \mathrm{scan}-1$. The compounds of this essential oil corresponding to the major peaks of each chromatogram were identified by comparing their retention times (RT) and mass 
spectra with those cited in the literature and given by the spectral library banks (NIST) (Kaloustian and Hadji-Minagloyou, 2012).

\section{Antifungal activity}

\section{Fungal strains}

Five clinical strains of Candida albicans (S1,S2,S3,S4 and S5) were isolated in the hospital laboratory of Mascara from vaginal infections of patients suffering from vulvovaginitis, identified by the chlamydospore formation test (Taschdjian, 1957). The blastèse test (Taschdjian et al., 1960). The API 20C system (Buesching et $\boldsymbol{a l}$., 1979), and the spectroscopic technique of MALDITOF (Bougnoux et al., 2013). Then stored in $25 \%$ glycerol at $-80^{\circ} \mathrm{C}$ (Denis, 2007). Yeast strains were refreshed in Sabouraud medium liquid at $37^{\circ} \mathrm{C}$ for $18 \mathrm{~h}$ After, these samples were inoculated on Sabouraud medium+ Chloramphenicol + actidione plate (BIO-RAD)

\section{Antifungal assay}

Antifungal activity of the essential oils was determined by disc diffusion method on Muller-Hinton agar (Anonyme, 2011). Inoculums of yeast adjusted to 0.5 McFarland with a densimat were spread with a sterile swab (Anonyme, 2011). Paper discs impregnated with $10 \mu \mathrm{l}$ of different concentrations of the essential oil prepared in $10 \%$ of DMSO, were placed on the surface of the agar. The treated Petri dishes were placed at $4^{\circ} \mathrm{C}$ for $2 \mathrm{~h}$ and then were incubated at $37^{\circ} \mathrm{C}$ for 24 to 48 h (Mighri et al., 2010). Measurements were done with a calliper to give the size of the zones of inhibition around the discs. In parallel, the antifungal standard (Fluconazole) using paper discs containing $64 \mu \mathrm{g} / \mathrm{ml}$ according to the modified protocol of M27-A2 (Anonyme, 2002). Then, the DMSO at $10 \%$ was used as a positive control.

\section{Micro-dilution determination of MIC and MFC}

The minimum inhibitory concentration (MIC) was determined using the broth microdilution method according to the National Committee for Clinical
Laboratory Standards (Anonyme, 2011). Sterile 96-well microplate was used for the assay. Five fungal strains of Candida albicans were cultured $18 \mathrm{~h}$ before a $37^{\circ} \mathrm{C}$ in Sabouraud-Chloramphenicol-actidione medium (BIO-RAD). In the first time, all the wells of microplate were filled with $50 \mu \mathrm{l}$ of Muller-Hinton broth (Joffin and Leyral, 2006). Then, a volume of $50 \mu \mathrm{l}$ of the chosen essential oil has been added to the first well. After, the same volume was removed to the second until the tenth well, to perform binary dilutions. Finally, the entire wells were also filled by inoculums adjusted at a wavelength of 530 which can reflect the unit of 0.5 MacFarland scale of each strain. The two last wells were used as controls. The well consisting Fluconazole $(64 \mu \mathrm{g} / \mathrm{ml})$, represented sterility control. Moreover, the second well represented the growth control. The fina volume in each well was $100 \mu \mathrm{L}$. Then, the microplate was incubated at $37^{\circ} \mathrm{C}$ for 24 to $48 \mathrm{~h}$. The first well without turbidity was represented the MIC $(\mathrm{mg} / \mathrm{ml})$. Experiments were performed in triplicate. The minimum fungal concentration (MFC) values were represented as the highest dilution (lowest concentration) of the sample, with no development of turbidity and without visible growth (Anonyme, 2011).

\section{Statistical analysis of data}

The experimental results are expressed as mean \pm standard deviation (SD) o multiple replicates. Then, the results were treated by ANOVA (one way), followed by t-test using SPSS software, version 19. The P values found below to 0.05 were considered statistically significant. However, the graphs were drawn by the Graphpad prism, version 7.0 software.

\section{RESULTS AND DISCUSSION}

\section{Yield and physicochemical proprieties of essential oils}

The aerial part of Artemisia herba alba asso (Aha), peel and leaves of Citrus aurantium (PCA and LCA) were subjected to hydrodistillation. However yields and the different characteristics of the essential oils are summarized in table (1).

Table 1 Yield and physicochemical proprieties of essential oils obtained from the aerial part of Artemisia herba alba asso, peel and leaves of Citrus aurantium

\begin{tabular}{llccc}
\hline \multirow{2}{*}{ Part of the plant } & Yield & Physical characteristics & \multicolumn{2}{c}{ Chemical characteristics } \\
\cline { 3 - 6 } & $(\%)$ & Density & RI & AI \\
\hline $\begin{array}{l}\text { Aerial part of Artemisia herba alba } \\
\text { asso }\end{array}$ & $0.4 \pm 0,0$ & 0.89 & 1.428 & 1.48 \\
\hline Peel of Citrus aurantium & $0.6 \pm 0,2$ & 0.88 & 1.472 & 1.85 \\
\hline Leaves of Citrus aurantium & $0.1 \pm 0,0$ & 0.86 & 1.457 & 1.69 \\
\hline
\end{tabular}

Following to the results obtained, yield extraction of the Aha essential oil was found in agreement with the previous works (Salido et al., 2004). Our findings were lower than that reported (Akrout, 2004). However, the essential oil yields were respectively $0.6 \%$ and $0.7 \%$ for leaves and peel (Boussaada and Chemli, 2006). Fresh peel yield $(0.3 \%)$ and leaves $(0.43 \%)$ of Citrus aurantium were reported (Essadik et al., 2014). These differences in yield extraction of essentia oils probably depend on the temperature, humidity, sunshine duration, the nature of the soil, the part of the plant used, the vegetative cycle and the extraction method performed (Bruneton, 1999). The refractive index of the three essentia oils were found to range from 1.428 to 1.457 . These results were found acceptable according to the compendium of French standards of essential oils These rates depend essentially on the content of monoterpenes and oxygenated derivatives. In addition, the AFNOR standard for essential oils has fixed a value of acid index less than 2 (Goudjil, 2016). So these samples are intact and can be stored for a long time until the moment of use.

\section{Chemical composition of the extracted essential oils}

The chemical composition of Artemisia herba alba asso essential oil was shown in table (2). From the data obtained, forty compounds were identified by GC-MS representing about $99.73 \%$ of the oil. The chemical constituents identified in this oil were classified into five classes. These were: monoterpenes hydrocarbon $(11.40 \%)$, oxygenated monoterpènes $(80.85 \%)$, monoterpenes alcohol $(2.43 \%)$ sesquiterpenes $(0.76 \%)$ and other constituents $(4.03 \%)$. Two oxygenated monoterpènes, camphor $(34.89 \%)$ and chrysantenone (19.60) were observed as the major components. Limonene and Eucalyptol (1-8 cineole) were present with very important percentages $(9.68 \%)$ and $(8.33 \%)$ respectively. In addition, nine compounds were reported for the first time in Artemisia herba alba asso essential oil, where the pinocarvone was found highest $(2 \%)$ compared to the others.
Table 2 Chemical compositions of Artemisia herba-alba essential oil

\begin{tabular}{|c|c|c|c|}
\hline $\mathbf{N}$ & Compounds & $\underset{a}{\text { Retention time }}$ & Percentage $(\%)$ \\
\hline 1 & Alpha-pinene & 6.2 & 0.4 \\
\hline 2 & Camphene & 6.7 & 1.6 \\
\hline 3 & 2-Béta- pinene & 7.7 & 0.2 \\
\hline 4 & Beta-myrcene & 8.1 & 1.6 \\
\hline 5 & Benzene $^{\mathrm{b}}$ & 9.6 & 0.1 \\
\hline 6 & Limonene & 9.8 & 9.6 \\
\hline 7 & Eucalyptol & 9.9 & 8 \\
\hline 8 & Isolyratol $^{\mathrm{b}}$ & 11.5 & 0.1 \\
\hline 9 & Cis- Sabinènehydrate & 11.7 & 0.1 \\
\hline 10 & 1,5-Heptadien-4-ol ${ }^{\mathrm{b}}$ & 12.2 & 0.3 \\
\hline 11 & 1,5-Heptadien-4-ol ${ }^{\mathrm{b}}$ & 13.3 & 4.5 \\
\hline 12 & Alpha-thujone & 13.6 & 2.5 \\
\hline 13 & Alpha-thujone & 14.2 & 1.0 \\
\hline 14 & Chrysantenone & 14.4 & 19.6 \\
\hline 15 & p-menth-2-en 1-ol & 14.6 & 0.5 \\
\hline 16 & Trans-pinocarveol & 15.5 & 0.8 \\
\hline 17 & p-menth-2-en 1-ol & 15.5 & 0.3 \\
\hline 18 & Camphre & 15.8 & 34.8 \\
\hline 19 & $\begin{array}{l}1,5,9, \\
\text { 11Tridecacatetraene }\end{array}$ & 16.3 & 0.2 \\
\hline 20 & Pinocarvone $^{\mathrm{b}}$ & 16.7 & 2.0 \\
\hline 21 & $(\mathrm{~S})$ cis-Verbenol $^{\mathrm{b}}$ & 16.8 & 1.2 \\
\hline 22 & Borneol & 17.3 & 2.0 \\
\hline 23 & Terpinen-4-ol & 17.8 & 0.7 \\
\hline 24 & Carvone & 18.3 & 0.2 \\
\hline 25 & Isolimonene & 18.7 & 0.3 \\
\hline 26 & Myrtenol $^{\mathrm{b}}$ & 18.8 & 0.1 \\
\hline 27 & Verbenone & 19.4 & 0.1 \\
\hline
\end{tabular}




\begin{tabular}{llll}
\hline 28 & Trans-piperitol & 19.5 & 0.3 \\
\hline 29 & Piperitoneoxide $^{\mathrm{b}}$ & 22.2 & 0.2 \\
\hline 30 & Chrysantenylacetate $_{31}$ & 22.5 & 0.7 \\
\hline 32 & 2-cyclohexene-1-one & 23.2 & 0.5 \\
\hline & Bornylacetate & 24.1 & 0.3 \\
33 & $\begin{array}{l}\text { 1-methyl-6- } \\
\text { methylenebicyclo[ }\end{array}$ & 25.6 & 0.2 \\
& 3.2.0]heptane & & \\
\hline & 1-methyl-6- & \\
34 & $\begin{array}{l}\text { methylenebicyclo[ } \\
\text { 3.2.0]heptane }\end{array}$ & 25.7 & 0.1 \\
\hline 35 & 1,3 cyclopentadiene & 26.1 & 0.5 \\
\hline 36 & 1-penten-3-ol & 28.3 & 0.1 \\
\hline 37 & 3,5-Heptadienal & 2.5 \\
\hline 38 & Germacrène & 31.1 & 0.2 \\
\hline 39 & Propanedinitrile & 36.0 & 0.6 \\
\hline 40 & (+) -aromadendrène $^{\mathrm{b}}$ & 42.4 & 0.2 \\
\hline Total & & 42.6 & 99.7 \\
\hline
\end{tabular}

\section{Identification of fungal strains}

It is clear to say, that these yeasts have the ability to form a germ tube, from a bud appears as a glove finger and without constriction at the base of the tube. However, the observation of a slide of RAT medium seeded by Candida albicans has confirmed that these strains are able of forming pseudomyceliums terminated by chlamydospores (Figure 1). The API 20C test has confirmed also that these yeasts probably correspond to the Candida albicans species. In parallel, the MALDI-TOF technique was used, which based on the demonstration of a spectral profile of the strain, the latter is compared with the reference spectra retained in the database. It should be noted that the five yeast strains correspond to Candida albicans, with scores totally greater than 1.5 , following to the MALDI-TOF spectra recorded by the Biotyper software.

Legend: a: Compounds listed in order of their retention time, b : Components reported for the first time in essential oil, the compounds written in bold are predominant.

Chromatographic analysis of the essential oil of the leaves of Citrus aurantium revealed ten constituents in a proportion of $100 \%$ of the total identified compounds (table 3). With the presence of three chemical classes: alcoho monoterpènes $(81.3 \%)$, Monoterpenes hydrocarbon $(7.01 \%)$, esters $(11.3 \%)$ and others $(0.39 \%)$. The major compound was linalool $(60.62 \%)$. While, a total of four compounds was identified from the essential oil of the peel of Citrus aurantium (table 3), which represented $82.85 \%$ of the oil extracted. Linalool $(42.33 \%)$ and limonene $(18.68 \%)$ were the dominant ones.

Table 3 Chemical composition of the essential oil of Citrus aurantium leaves and peels

\begin{tabular}{lcccc}
\hline $\begin{array}{l}\text { Part of the } \\
\text { plant }\end{array}$ & \multicolumn{2}{c}{ Citrus aurantium leaves } & \multicolumn{2}{c}{ Citrus aurantium peels } \\
\hline $\begin{array}{l}\text { Chemical } \\
\text { compounds }\end{array}$ & $\begin{array}{c}\text { Retention } \\
\text { time }^{\text {a }}(\mathrm{min})\end{array}$ & $\begin{array}{c}\text { Percentage } \\
(\%)\end{array}$ & $\begin{array}{c}\text { Retention } \\
\text { time }^{\text {a }}(\mathrm{min})\end{array}$ & $\begin{array}{c}\text { Percentage } \\
(\%)\end{array}$ \\
\hline Beta-myrcene & 8.1 & 0.5 & - & - \\
\hline Limonene & - & - & $\mathbf{9 . 8}$ & $\mathbf{1 8 . 6}$ \\
\hline $\begin{array}{l}\text { Trans-beta- } \\
\text { Ocimene }\end{array}$ & 10,5 & 0,3 & - & - \\
\hline Linalool oxyde & - & - & 11.8 & 10.6 \\
\hline Linalol & $\mathbf{1 3 . 2}$ & $\mathbf{6 0 . 6}$ & $\mathbf{1 3 . 2}$ & $\mathbf{4 2 . 3}$ \\
\hline Terpineol alpha & $\mathbf{1 8 . 7}$ & $\mathbf{1 4 . 3}$ & 18.7 & 11.1 \\
\hline Nerol & 20.5 & 1.3 & - & - \\
\hline Linalylacetate & 22.1 & 11.3 & - & - \\
\hline Geraniol & 22.2 & 4.9 & - & - \\
\hline Nerylacetate & 28.9 & 2.0 & - & - \\
\hline Geranylacetate & 30.1 & 4.0 & - & - \\
\hline $\begin{array}{l}\text { Di-n- } \\
\text { butylphthalate }\end{array}$ & 61.6 & 0.3 & - & - \\
\hline Lend: & & & & - \\
\hline
\end{tabular}

Legend: a: Compounds listed in order of their retention time, $\mathrm{b}$ : Components reported fo the first time in essential oil, the compounds written in bold are predominant

After comparison, with the previous works. The principal component of Artemisia oil was camphor $19.4 \%$ (Dob and Benabdelkader, 2006). The bthujone (58\%) was found as a major compound (Mighri et al., 2010). Oxygenated monoterpenes constituted the main chemical class of the oil $(77.78 \%)$ and they were represented by camphor $(39.5 \%)$, chrysanthenone (10.38\%), 1,8-cineole $(8.6 \%), \alpha$-thujone $(7.03 \%)$, borneol $(3.35 \%)$ and bornyl acetate $(2.52 \%)$ as the principal components (Lakehal et al., 2016). So we can deduce that this essential oil can induce different biological activities because it has new compounds found for the first time compared to the other oils. In this study, analyzes of the essential oils of PCA and LCA showed a similarity with different results. The main components of petitgrain oil were linalool (36.8\%), linalyl acetate $(22.1 \%)$, $\alpha$-terpineol $(11.7 \%)$, geraniol $(7.1 \%)$ and geranyl acetate $(6 \%)$ (Boussaada and Chemli, 2006). Limonene was found as a major compound with a percentage of $(90 \%)$ in biomass of Citrus aurantium harvested in the Moroccan province of Taounate (EL-Akhal et al., 2014). The pee essential oil consisted almost exclusively of monoterpene hydrocarbons, which alone account for $94 \%$ of the total oil, with limonene as major oil constituent (90.6\%) (Boussaada and Chemli, 2006). In the light of these results, Chemical variety of the essential oils depended especially on growing temperature, altitude (Sanli and Karadogan, 2017). Age of the plant (young or adult), the state of the plant, material used (dried or fresh), the part of the plant used, time of collection, etc. (Ben Marzoug et al., 2011).

Antifungal activity 


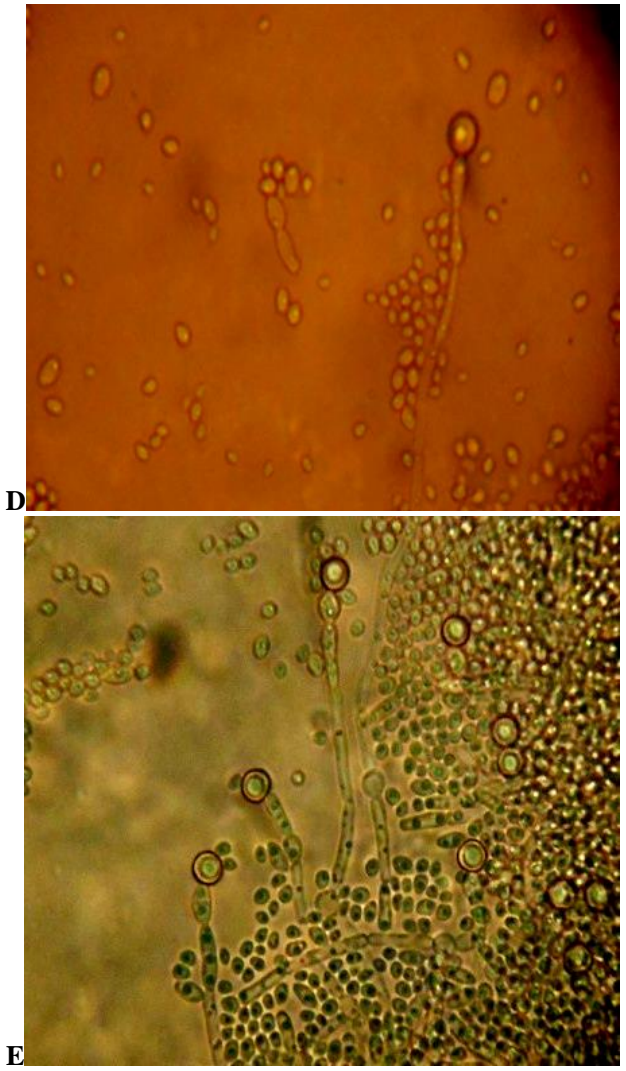

In microbiology, only the Candida albicans species produces chlamydospores and germ tubes (Joffin and Leyral, 2006). In addition, the rapid identification by kits such as API $20 \mathrm{C}$ AUX has been widely used and they have been designed for clinical diagnostic purposes. In most cases, $C$. albicans assimilates xylose and $\alpha$-methyl-D-glucoside (Ng et al., 2014). While the most reliable galleries at this identification are API 20C Aux and ID 32C (Anane and Khalfallah 2007). A study revealed that the MALDI-TOF MS system appears to be a fast and powerful technique for the accurate identification of Candida species routinely isolated in medical laboratories (Lacroix et al., 2014). Note also that the spectral profile differs from one genus to another and from one species to another (Bougnoux et al., 2013). So these results let us see that this identification is precise.

\section{Evaluation of the antifungal activity by the agar diffusion test}

The Artemisia herba alba asso essential oil was chosen for the study of the antifungal activity. And it was selected among the other oils, according to its large content of chemical compounds, revealed by GC-MS. The present study showed that this essential oil was characterized by its important antifungal activity, against the five isolated clinical strains of Candida albicans. The DMSO $(10 \%)$ did not show antifungal activity against the tested fungal strains (negative control).But the inhibitory effect was found to be related to the concentration of the essential oil and the tested yeast strain. The tested essential oil was characterized by its significant effect $(\mathrm{P}<0.05)$ against the third strain with inhibition zones between $(27 \pm 3-41 \pm 0.6 \mathrm{~mm})$. Whereas, it showed the least antifungal effect. In case of the ford strain with zone inhibition ranging from (10 $\pm 1.5-29 \pm 0.7 \mathrm{~mm}$ ). The positive control (Fluconazole) was marked by low effect ranging from $(15-28 \pm 2.9 \mathrm{~mm})$ compared to the different concentrations of the essential oil. The results of this study are summarized in table (2).

Figure 1 Microscopic observation of Candida albicans chlamydospores. a: strain 1, b: strain 2, c: strain 3, d: strain 4, e: strain 5

Table 4 Antifungal activity of Artemisia herba alba asso essential oil against five clinical strains of Candida albicans

\begin{tabular}{|c|c|c|c|c|c|c|}
\hline \multirow{2}{*}{ The compound used } & \multirow[b]{2}{*}{$\begin{array}{l}\text { Concentrations } \\
(\mathrm{mg} / \mathrm{ml})\end{array}$} & \multicolumn{4}{|c|}{$\begin{array}{l}\text { Inhibition zone diameter } \\
(\mathrm{mm} \pm \text { SD })\end{array}$} & \multirow[b]{2}{*}{ S5 } \\
\hline & & S1 & S2 & S3 & S4 & \\
\hline \multirow{4}{*}{$\begin{array}{l}\text { Aerial part of Artemisia herba } \\
\text { alba asso }\end{array}$} & 50 & $35 \pm 0.3^{*}$ & $32 \pm 0.6^{*}$ & $41 \pm 0.6^{*}$ & $29 \pm 0.7^{*}$ & $30 \pm 2^{*}$ \\
\hline & 25 & $30 \pm 1.1^{*}$ & $23 \pm 0.6^{*}$ & $38 \pm 0.6^{*}$ & $25 \pm 3^{*}$ & $30 \pm 1.3^{*}$ \\
\hline & 12.5 & $20 \pm 1.5^{*}$ & $19 \pm 0.0$ & $27 \pm 3^{*}$ & $22 \pm 0.6^{*}$ & $22 \pm 0.5$ \\
\hline & 6.25 & $12 \pm 0.6$ & $11 \pm 0.8$ & $24 \pm 0.8^{*}$ & $10 \pm 1.5$ & $15 \pm 2$ \\
\hline Fluconazole (Positive control) & 0.064 & 17 & $19 \pm 0.6$ & $15 \pm 0.0$ & $16 \pm 1$ & $28 \pm 2.9$ \\
\hline DMSO (Negative control) & - & 0 & 0 & 0 & 0 & 0 \\
\hline
\end{tabular}

Legend: S1,S2,S3,S4 and S5= Strain 1; Strain 2, Strain3, Strain 4 and Strain 5; SD- standard deviation; Values are means \pm standard deviation of three separate experiments. Significant effect $(\mathrm{P}<0.05)$.

On the other hand, the antifungal activity of Fluconazole against the Candida albicans: ATCC 90029 strain was close to our results with an inhibition diameter equal to $(20.07 \pm 0.7 \mathrm{~mm})$ (EL Alama et al., 2017). Moreover, this essential oil was marked by a potent antifungal activity especially against S3 and S1 strains compared to the same studies. In parallel, the Candida albicans MTCC183 strain is found resistant to Fluconazole with no zone of inhibition around the disks impregnated with antifungal solution (Khan et al., 2012).

Following to the results found during the study of the antifungal activity of the Artemisia herba alba asso essential oil. Different diameters have been found $(14.3 \pm 0.4 \mathrm{~mm}),(13.3 \pm 0.6 \mathrm{~mm}),(16.0 \pm 0.0 \mathrm{~mm})$ et $(19.0 \pm 1.0 \mathrm{~mm})$ using four types of essential oils of Aha (I,II,III et IV) respectively with a dose of (10 $\mu \mathrm{L} / \mathrm{disc}$ ) of each one (Mighri et al., 2010). Otherwise, the effect of different doses of essential oil of Artemisia herba alba asso on the fungal strains namely $0.05 \%, 0.25 \%$ which indicate the mycelial decay of Stemphylium solani, Fusarium moniliforme, Fusarium solani and Fusarium oxysporum tested. In addition, the concentration of $0.75 \%$ completely prevented the growth of al mycelial strains tested (Goudjil, 2016).

\section{Determination of MIC and MFC}

The results of the MIC and MFC were presented in figure (2). The essential oil showed a significant inhibitory effect against the five fungal clinical strains within a range of concentrations from $(1.95 \pm 0.05 \mu \mathrm{l} / \mathrm{ml}$ to $31.25 \pm 4.5 \mu \mathrm{l} / \mathrm{ml})$ While the lowest MIC $(1.95 \pm 0,05 \mu \mathrm{l} / \mathrm{ml})$ and MFC $(3.75 \pm 1.25 \mu \mathrm{l} / \mathrm{ml})$ were observed to be effective against the third stain. The essential oil exhibited the lowest inhibitory effect against the fourth strain with MIC $(31.25 \pm 4.5 \mu \mathrm{l} / \mathrm{ml})$ and MFC $(62.5 \pm 2.6 \mu 1 / \mathrm{ml})$. The different effects of Aha essential oil on strains may be due to the variation of genotype, despite that the five fungal strains belong to the same species of Candida albicans. The essential oil of Artemisia herba alba asso exerted a fungicidal effect against the strains (S1, S3, S4 and S5) because of their CMF / MIC ratios $\leq 2$. However, its effect is considered fungistatic against the strain S3.

\section{Antifungal activity}

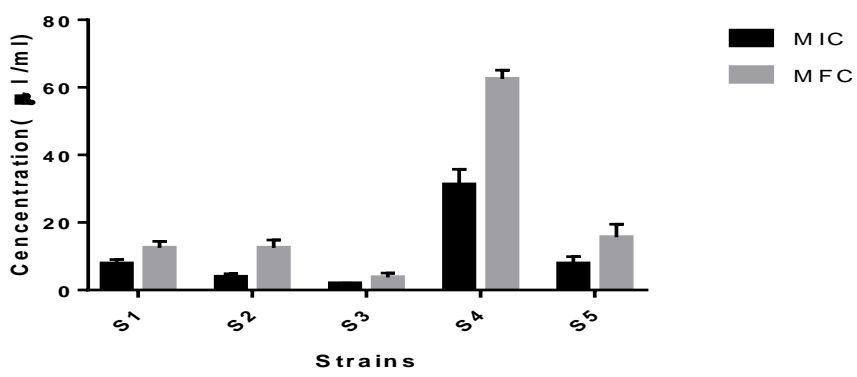

Figure 2 In vitro MIC and MFC $(\mu 1 / \mathrm{ml})$ values of essential oil of Artemisia herba alba asso against five clinical strains of Candida albicans.

The antifungal activity of Artemisia herba alba asso essential oil against the strain (S3) is found close to that found of Fluconazole against the Candida albicans reference strain (733) with a MIC value equal to $(2 \mu \mathrm{g} / \mathrm{ml})$ (Grillot $\boldsymbol{e}$ al., 2007). However, Yan et al., (2012) found a lower MIC value $(1 \mu \mathrm{g} / \mathrm{mL})$ of the same antifungal against (Candida albicans: ATCC 90028). More, two inhibitory concentrations of Fluconazole $(0.25$ and $0.5 \mu \mathrm{g} / \mathrm{ml})$ against two 
strains of Candida albicans (ATCC 90028 and ATCC 24433) respectively have been reported previously (Ryder et al., 1998).

In addition, the results of the determination of MIC and MFC of Artemisia herba alba asso essential oil were highest than that reported, where they found that the essential oils of Mentha piperita and Mentha longifolia exhibited fungistatic and fungicide against Candida albicans with very low MFC $(8 \mu \mathrm{l} / \mathrm{ml}$ and 15 $\mu \mathrm{l} / \mathrm{ml}$ ) respectively (Mimica-Dukic et al., 2003). Lowest values of MIC and MFC $(10.5 \mu \mathrm{g} / \mathrm{mL})$ were found in Iranian Achillea wilhelmsii $L$ essential oil against Candida albicans. Moreover, $C$. albicans and $E$. coli are the most sensitive microorganisms (Kazemi and Rostami, 2015). Otherwise, the CMF / MIC ratios were found between (1 and 15.97), in case of Artemisia sieberi essential oil against Candida glabrata (Khosravi et al., 2011).

The richness of this essential oil in oxygenated monoterpenes $(80.85 \%)$ and monoterpenes hydrocarbon $(11.4 \%)$ can explain its potent antifungal effect against isolated strains. It was shown, that monoterpenes hydrocarbons and oxygenated monoterpenes in essential oils are able to destroy cellular integrity resulting in respiration inhibition and permeability alteration (Cox et $\boldsymbol{a l}$., 2000) Moreover, Camphor, $\alpha$-pinene, $\beta$-pinene, and limonene inhibit respiratory activity in yeast mitochondria (Tepe $\boldsymbol{e t}$ al., 2005). Indeed, the antimicrobial activity may be the result of a synergistic effect between several compounds of this EO (Felice et al., 2004).

\section{CONCLUSION}

Antibiotic resistance is now one of the most serious threats to global health. In this purpose, the present study was a contribution to enhance the use of two medicinal plants strongly used in the region of Mascara city. The main results indicate that the Aha essential oil was rich in different classes of terpenoids. However, this essential oil was characterized by a strong antifungal activity against five clinical strains of Candida albicans compared to a synthetic antifungal. According to the results, this plant extract can be used as a new potential source of antifungal agents, among various diseases.

Acknowledgments: The authors are thankful the University of Mascara for financial support provided. And Mr GABALDÓN José Antonio for his best reception in his laboratory with his kind team during one month.

Conflicts of interest: The authors declare no conflict of interest.

\section{REFERENCES}

Ainane, A., Khammour, F., Talbi, M., Charaf, S., Elabboubi, M., El Kouali, M., Bricha, M. R., Abba, E. H., Cherroud S.,Tarik, A. (2018). Chemical characterizations of the aromatic compositions of two citrus species: citrus aurantium and citrus reticulate. MOJ Drug Des Develop Ther, 2(3), 80-83. doi: 10.15406/mojddt.2018.02.00032

Akrout, A. (2004). Essential oil study of some pastoral plants from Matmata (south Tunisia). Options Mediterranean, (62), 289-292. https://www.researchgate.net/publication/238067859

Anane, S., Khalfallah, F. (2007). Diagnostic biologique des candidoses systémiques: difficultés et perspectives. Pathologie Biologie, (55), 262-272. do : 10.1016/j.patbio.2006.03.003.

Anonyme, 2001 Encyclopédie des plantes médicinales. (Identification, préparation et soins). Royaume-Uni : Larousse.

Anonyme 2002. The Clinical and Laboratory Standards Institute (CLSI). M27A2. Reference method for broth dilution antifungal susceptibility testing of yeasts; approved standard-second edition. Wayne: Clinical and Laboratory Standards

https://www.google.com/search?ei=SGghXKaZErGflwSiyIzQAg\&q=The+Clinic al+and+Laboratory+Standards+Institute+\%28CLSI\%29.+M27A2.+2002\&oq=Th e+Clinical+and+Laboratory+Standards+Institute+\%28CLSI\%29.+M27-

A2.+2002\&gs_l=psy

Anonyme 2011. National Committee for Clinical Laboratory Standards (NCCLS). M100-S11. Performance standards for antimicrobial susceptibility testing: Eleventh informational supplement, Wayne, PA, USA, https://www.google.com/search?ei=iWghXIWCC8HYacfZm4gG\&q=National+ Committee+for+Clinical+Laboratory+Standards+\%28NCCLS\%29.+M100S11.+ $2011 \&$ oq $=$ National+Committee + for + Clinical+Laboratory+Standards $+\% 28 \mathrm{NCC}$ LS\%29.+M100-S11.+2011\&gs_l=psy-

ab.3...46484.53785..54172...0.0..0.181.826.0j6.....0...1j2..gws

Ben Marzoug, H.N., Romdhane, M., Lebrihi, A., Mathieu, F., Couderc, F., Abderraba, M., Larbi Khouja, M., and Bouajila, J. (2011). Eucalyptus oleosa essential oils: chemical composition and antimicrobial and antioxidant activities of the oils from different plant parts (stems, leaves, flowers and fruits) Molecules, 16(2), 1695-709. doi: 10.3390/molecules16021695.

Bougnoux, M.E., Angebaulta, C., Letob, J., Berettib, J.L. (2013). Identification des levures par spectrometrie de masse de type MALDI-TOF. Revue francophone des laboratories, (450), 63-70. Doi : RFL-03-2013-43-450-1773035X-101019-201207574

Boussaada, O., Chemli, R. (2006). Chemical Composition of Essential Oils from Flowers, Leaves and Peel of Citrus aurantium L. var. amara from Tunisia.
Journal of Essential Oil Bearing Plants, (9), 133-139. https://doi.org/10.1080/0972060X.2006.10643484

Bruneton, J. (1999). Terpenoides et stéroides in Pharmacognosie, phytochimie. Plantes médicinales, $4{ }^{\text {th }}$ Ed. London Intercept: Lavoisier.

Buesching, W.J., Kurek, K., Roberts, G.D. (1979). Evaluations of the Modified API 20C System for Identification of Clinically Important Yeasts. Journal of Clinical Microbiology, 9(5), 565-569. 0095-1137/79/05-0565/05\$02.00/0

Cox, S.D., Mann, C.M., Markham, J.L., Bell, H.C., Gustafson, J.E., Warmington, J.R., Wyllie, S.G. (2000). The mode of antimicrobial action of the essential oil of Melaleucaalternifolia (tea tree oil). Journal of applied microbiology, 88(1), 170-175. https://doi.org/10.1046/j.1365-2672.2000.00943.x Denis, F. (2007). Bactériologie médicale: Techniques usuelles. Issy-lesMoulineaux, France : Elsevier Masson.

Djeridane, M., Yousfi, B., Nadjemi, D., Boutassouna, P., Vidal, N. (2006) Antioxidant activity of some Algerian medicinal plants extracts containing phenolic compounds. Food Chemistry, 97, 654-660. https://doi.org/10.1016/j.foodchem.2005.04.028

Dob, T., Benabdelkader, T. (2006). Chemical Composition of the Essential Oil of Artemisia herba-alba Asso Grown in Algeria. Journal of Essential Oil Research, 18(6), 685-690. DOI: 10.1080/10412905.2006.9699206

EL-Akhal, F., Guemmouh, R., Greche, H., El Ouali Lalami, A. (2014) Valorisation en tant que bioinsecticide de deux huiles essentielles de Citrus sinensis et Citrus aurantium cultivées au centre du Maroc (Valorization as a bioinsecticide of essential oils of Citrus sinensis and Citrus aurantium cultivated in center of Morocco). Journal of Materials and Environmental Science, 5 (S1), 2319-2324. https://www.researchgate.net/publication/281999824.

EL Alama, H., EL Aissami, A., Benmoussa, A ., Ait Haj Said, A., Arahou, M., EL Alaoui-Faris, F.E. (2017). Cinétique des interactions huile essentielleantifongique. Bulletin de la Société Royale des Sciences de Liège, 86, 67 - 77 DOI: $10.25518 / 0037-9565.7162$

Essadik, F., Habsaoui, A., Kribii, A., Ounine, K., Kribii, A., Rifi, H. (2014). Evaluation de l'activité antioxydante et antibactérienne des extraits des oranges amères (Citrus aurantium L.). in : Proceedings of « Innovation Thérapeutique du Fondamental à l'Appliqué », Rabat :17-18. DOI: 10.13140/2.1.3844.3843.

Felice, S., Francesco, N., Nelly, A.A., Maurezio, B., Werner, H. (2004) Composition and antimicrobial activity of the essential oil of Achilleafalcata L. Flavour and Fragrance Journal. 20 (3), 291-294. https://doi.org/10.1002/ffj.1411

Goudjil, M. B. (2016). Chemical composition, antimicrobial and antioxidant activity of three aromatic plants. Phd_dissertation. Kasdi Merbah University, Algeria.

Grillot, R. (2007). Anidulafungine : activité in vitro sur les levures et les champignons filamenteux d'intérêt clinique. Réanimation 16, S261-S266. doi 10.1016/S1624-0693(07)78763-7.

Haouari, M., Ferchichi, A. (2009). Essential Oil Composition of Artemisia herba-alba from Southern Tunisia. Molecules, 14, 1585-1594. DOI:10.3390/molecules14041585

Joffin, J.N., Leyral, G. (2006). Microbiologie technique: Dictionnaire des techniques, volume 1. Bordeaux : Canopé - CRDP de Bordeaux.

Kaddem, S. (1993). Les plantes médicinales en Algérie. Algérie : OPU

Kazemi, M., Rostami, H. (2015). Chemical composition and biological activities of Iranian Achillea wilhelmsii L. essential oil: a high effectiveness against Candida spp. and Escherichia strains. Natural Product Research, 29 (3), 286-288. doi: 10.1080/14786419.2014.953949.

Khosravi, A.R., Shokri, H., Kermani, S., Dakhili, M., Madani, M., Parsa, S (2011). Antifungal properties of Artemisia sieberi and Origanum vulgare essential oils against Candida glabrata isolates obtained from patients with vulvovaginal candidiasis. Journal de Mycologie Médicale , (21), 93-99. doi: 10.1016/j.mycmed.2011.01.006

Kaloustian, J., Hadji-Minagloyou, F. (2012). Contrôles chromatographiques. In La connaissance des huiles essentielles : qualitologie et aromathérapie (Entre science et tradition pour une application médicale raisonnée). Verlag France : Springer.

Khan, M. S. A., Malik, A ., Ahmad, I. (2012). Anti-candidal activity of essential oils alone and in combination with amphotericin B or fl uconazole against multidrug resistant isolates of Candida albicans. Medical Mycology January, 50, 33 42. doi: 10.3109/13693786.2011.582890.

Kurian, A., Sankar, A. M. (2007). Medicinal Plants., New Delhi: Publishing New India.

Lacroix, C., Gicquel, A., Sendid, B., Meyer, J., Accoceberry, I., François, N., Morio, F., Desoubeaux, G., Chandenier, J., Kauffmann-Lacroix, C., Hennequin, C., Guitard, J., Nassif, X., Bougnoux, M.E. (2014). Evaluation of two matrixassisted laser desorption ionization-time of flight mass pectrometry (MALDITOF MS) systems for the identification of Candida species. Clinical Microbiology and Infection, 20(2),153-8. doi: 10.1111/1469-0691.12210.

Lakehal, S., Meliani, A., Benmimoune, S., Bensouna, S.N., Benrebiha, F.Z. Chaouia, C. (2016). Essential Oil Composition and Antimicrobial Activity of Artemisia herba- alba Asso Grown in Algeria. Medicinal chemistry, 6 (6), 1-5 doi:10.4172/2161-0444.1000382

Mighri, H., Hajlaoui, H., Akrout, A., Najjaa, H., Neffati, M. (2010). Antimicrobial and antioxidant activities of Artemisia herba-alba essential oil 
cultivated in Tunisian arid zone. C. R. Chimie, (13), 380-386. doi : 10.1016/j.crci.2009.09.008.

Mimica-Dukic, N., Bozin, B., Sokovic, M., Mihajlovic, B., Matavulj, M. (2003). Antimicrobial and antioxidant activities of three Mentha species essential oils. Planta Medica, (69), 413-419. doi: 10.1055/s-2003-39704.

Mohamed, A. H. H., El-Sayed, M. A., Hegazy, M. E., Helaly, S. E., Esmail, A. M., Mohamed, N. S. (2010). Chemical Constituents and Biological Activities of Artemisia herba-alba. Rec. Nat. Prod, 4(1), 1-25. https://www.researchgate.net/publication/41391726_Chemical_Constituents and Biological Activities of Artemisia herba-alba.

Mondello, L., Casilli, A., Tranchida, P. Q., Dugo, P. and Dugo, G. (2005) Comprehensive two-dimensional GC for the analysis of Citrus essential oils. Flavour and Fragrance Journal, 20, 136-140. https://doi.org/10.1002/ffj.1506.

Ng, K.P., Soo-Hoo, T.S., Na, S.L. (2014). Yeasts and yeast like fungi. In: a Guide to the Study of Basic Medical Mycology. Singapore : Partridge Publishing Singapore.

Ryder, N. S., Wagner, S., Leitner, I. (1998). In Vitro Activities of Terbinafine against Cutaneous Isolates of Candida albicans and Other Pathogenic Yeasts. ANTIMICROBIAL AGENTS AND CHEMOTHERAPY, 42 (5), 1057-1061. doi: 10.1128/AAC 42.5.1057.

Salido, S., Valenzuela L.R., Altarejos, J., Nogueras, M., Sanchez, A., Cano, E. (2004). Composition and infraspecific variability of Artemisia herba-alba from southern Spain. Biochem Syst Ecol, (32), 265-277. doi:10.1016/j.bse.2003.09.002.

Sanli, A., Karadogan, T. (2017). Geographical impact on essential oil composition of endemic Kundmannia anatolica HUB.-MOR. (Apiaceae). African Journal of Traditional Complementary and Alternative Medicines, 14 (1), 131 -

137. doi: 10.21010/ajtcam.v14i1.14

Taschdjian, C.L. (1957). Routine Identification of Candida albicans: Current Methods and a New Medium Source. Mycologia, (49), 332-338. doi: $10.2307 / 3755683$.

Taschdjian, C.L., Claire, L., Burchall, J.J., . Kozinn P.J. (1960). American journal of diseases of children, (99), 212.

Tepe, B., Daferera, D., Sokmen, A., Sokmen, M., Polissiou, M. (2005). Antimicrobial and antioxidant activities of the essential oil and various extracts of Salvia tomentosa Miller (Lamiaceae). Food Chemistry, (90), 333-340 doi: 10.1016/j.foodchem.2003.09.013.

Yan, Z., Hua, H., Xu, Y and Samaranayake, L. P. (2012). Potent Antifungal Activity of Pure Compounds from Traditional Chinese Medicine Extracts against Six Oral Candida Species and the Synergy with Fluconazole against AzoleResistant Candida albicans. Evidence-Based Complementary and Alternative Medicine, 1-6. doi:10.1155/2012/106583.

Zarrad, K., Ben Hamouda, A., Chaieb, I., Laarif, A., Mediouni-Ben Jemâa, J (2015). Chemical composition, fumigant and anti-acetylcholinesteraseactivity of the Tunisian Citrus aurantium L. essential oils. Industrial Crops and Products, 76, 121-127. http://dx.doi.org/10.1016/j.indcrop.2015.06.039. 